\title{
Recreational Centers in Chisinau in the Vision of Visual Artists
}

\section{Natalia PROCOP}

\begin{abstract}
One of the genres of easel painting that remains less pretentious to politics is landscape. The city of Chisinau, one of the most important cities of the Republic, was and remains a source of inspiration for artists Eugenia Gamburd, Rostislav Ocușco, Mihail Petric, Filimon Hămuraru, Ludmila Țonceva, Vasile Toma, Inesa Țîpina, Petru Jireghea, Ion Jumatii, Ion Chitoroagă, Florentin Leancă and others. That is one of the topics addressed by artists reflecting moments of relaxation, rest, sports - recreational centres (parks, lakes, stadiums etc.). This article analyzes the paintings from the collection of the National Museum of Art of Moldova, but also the private collections of plastic artists concerning the rest areas of Chisinau. These paintings made on the subject under research can be attributed not only to the landscape genre but also, in some cases, to genre painting. The subject becomes current for painters with the arrangement of the capital's parks: The square of the Ensemble of the Metropolitan Cathedral of Chisinau, the Public Garden of Chisinau, the Botanical Garden, the Valley of Roses park, the Valley of Mills park, the Ghidighici Reservoir, the Dinamo Stadium etc.
\end{abstract}

Keywords: Chisinau, recreational centres, visual arts, painting.

The relaxation area of the urban spaces is the subject of inspiration for visual artists from different periods. Public parks, sports grounds or children's playgrounds are subjects without ideological claims, which are meant to bring the spectator back to the area of relaxation and comfort.

This study analyzes the works of art from the properties of the National Museum of Art of Moldova (NMAM) that address the theme of recreational centres in Chisinau, starting with the first acquisitions in 1946, paintings dating from 1895 to the 21st century. The subject is evoked in the paintings of Rostislav Ocușco, Mihail Petric, Filimon Hămuraru, Ludmila Țonceva, Vasile Toma, Inesa T, îpina, Petru Jireghea, Ion Jumatii, Ion Chitoroagă, Florentin Leancă and others. The cycles of works from the personal collections of the visual artists who approached the respective subject were also subjected to the analysis.

The artistic creation presented in this study demonstrates the evolution of the city from a quiet, green area, where life flows slowly, with values for family, physical and spiritual health, traditional values for those times, evolving to the rapid urbanization of the city, building constructions in the park, arranged sta- 
diums, the multitude of children's cradles. All these changes could be achieved with the economic development of the union republics. The evolution of Chisinau and the people of Chisinau can be seen not only in the clothing of the time, the scenery of the landscape, the architecture adjacent to the recreational areas, but also through the approach technique and the style of the artists.

The scientific problem solved in the article is the definition of the role of painting with the theme of recreational areas in Chisinau in the context of the landscape genre in Moldova, which made possible the presentation of its evolutionary process. The objectives of this article are: the capitalize on the documentary sources concerning the studied topic present in the Republic's archives and libraries; the identification of the methodological-technological specificity in the practical realization of the works of the local painters who made the theme of the leisure areas; the cataloging the names of the artists in the field of painting and of the most important creations from the NMAM plastic fund to the targeted theme.

The subject of recreational areas in Chisinau is a subject that has not been researched. Landscape as a genre of fine arts was studied in the doctoral thesis "Landscape in fine arts in Moldova”, author Angela Munteanu. In classifying the types of landscape "according to the nature of the images", the author lists only the urban landscape ${ }^{1}$, without detailing its specificity.

In the article „Urban landscape in the painting of Moldova in the twentieth century - early twenty-first century" Ludmila Toma highlights the specific trends of paintings with the theme of the urban landscape (representing the cities of Chisinau, Balti, Paris etc.), made by local artists ${ }^{2}$.

The lack of field research impelled the need for this study, the realization of which was possible based on the plastic funds of MNAM and the National Archive of the Republic of Moldova.

Painting from the modern period, the 1900s from NMAM properties presents Chisinau as a village, with courtyard houses. The visual artists who approached the theme of Chisinau from that period are Vladimir Ocușco, Theodor Kiriacoff, Vasile Blinov, Saul Rabover and others. The first works from the plastic fund of NMAM in the 19th century subjected to research are characterized by landscapes of a realistic aesthetic ideology (Figure 1, 2). Ivan Stepankovski is a visual artist who painted the park in Chisinau, a work that can be attributed not only to the landscape genre but also to the genre painting. The

1 Urban, with variants of architectural or industrial landscape, working, Munteanu Angela. Peisajul în artele plastice din Moldova (Chișinău, 2016): 36.

2 Toma Ludmila. „Peisajul urban în pictura Moldovei din secolul al XX-lea - începutul secolului al XXI-lea." Arta (2017): 113-119. 
composition "Walk (In the Public Garden of Chisinau)" (1895, oil, canvas, 400 $\times 320 \mathrm{~mm}, \mathrm{NMAM}$ ) is the first dating of the Chisinau city in the painting from the museums' properties. The author I. Stepankovski recounts the historical period in which the action takes place, indicated by the wooden fence landscape ${ }^{3}$, but also by the vintage clothing.

Emphasizing the same subject, although with a different panorama, is the painting of N. Ratok "Entrance to the park in Chisinau" (1908, oil, canvas, 230 $\times 350 \mathrm{~mm}, \mathrm{NMAM})$, the fence that delimits the park, being similar to the current one. The authors, using the volumetric spatial treatment, the falling shadow and light, the elements of the landscape specific to the period, manage to reproduce the atmosphere of time, the state of the day etc.

The post-war period in painting is characterized by the subject of recreational centres that develop with the urbanization of Chisinau, landscaping of parks, accumulation lakes, such as Chisinau Public Garden, Valley of Mills, Valley of Roses, Ghidighici Lake, Botanical Garden etc. All these places are points of attraction for both the inhabitants of the capital, the visitors and the visual artists.

The first decade of the post-war period largely reflects the city destroyed during the bombings. One of the artists to whom she managed to present the sunny capital, ignoring the tendency of the socialist spirit manifested at that time, is Eugenia Gamburd. During the years 1930-1934 she studied at the painting department of the School of Fine Arts in Chisinau ${ }^{4}$, and during the years 1934-1936, she continued her studies at the Academy of Arts in Bucharest $^{5}$. In 1940 the artist returned to the country, and after the Second World War, she showed her interest in the following subjects: "Reconstruction of Chisinau" (1947) and "Chisinau under construction" (1947-1948). Gamburd is concerned with changing the appearance of the city, depending on the state of the day, mainly focusing on the falling shadows, the intensity of sunlight, etc. In the NMAM collection, there are a series of landscapes of the artist that denotes a state of relaxation, in which people are represented resting “The Square” (1945, $192 \times 267 \mathrm{~mm})$, “Al. Pushkin park from Chisinau” (1945, $285 \times 388 \mathrm{~mm})$.

3 The public garden was founded in 1820 by the architect Bogdan Eitner, surrounded by a wooden fence, A.S. Weinberg. Chișinăul în trecut și prezent. Schiță istorică (Chișinău, 1936): 23.

4 Professor Șneer Kogan, Ludmila Toma. Eugenia Gamburd (Israel: Zvi Printing Corporation, 2007): 129.

5 Jean Alexandru Steriadi's studio, Toma. Eugenia Gamburd..., 129. 


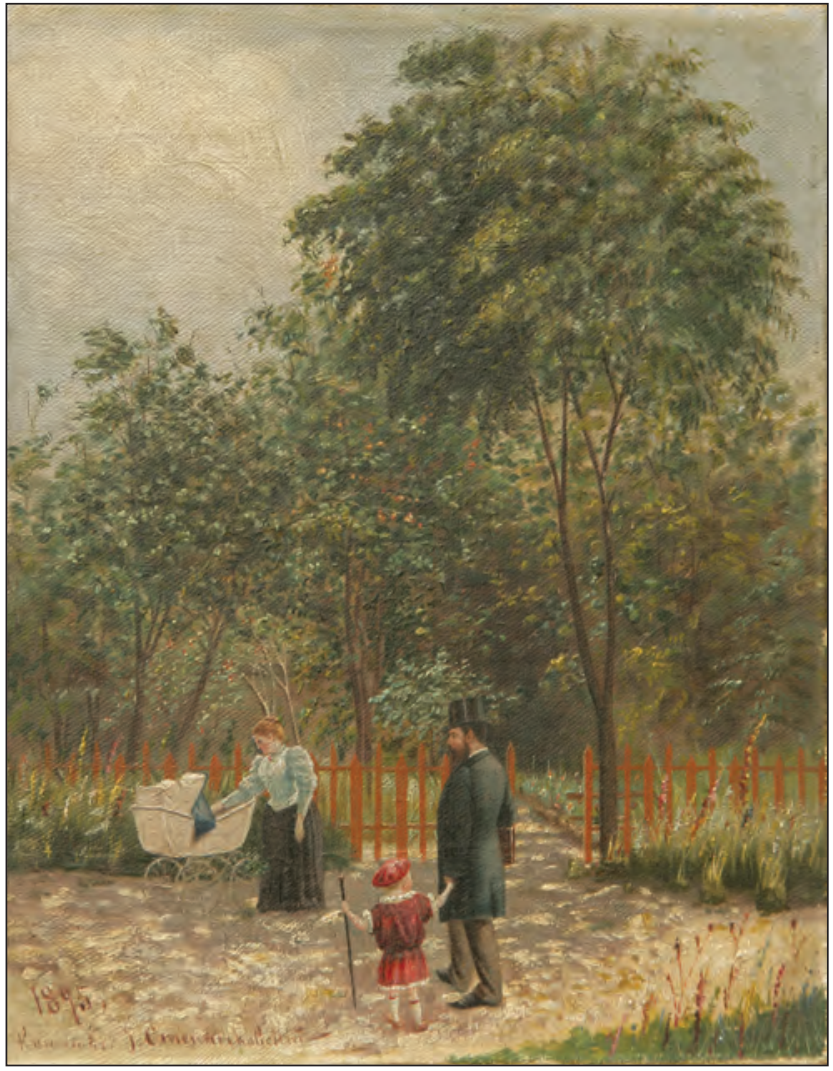

Figure 1. Ivan Stepankovski "Walk (In the Public Garden of Chisinau)", 1895 (oil, canvas, $400 \times 320 \mathrm{~mm}, \mathrm{NMAM})$.

In 1947, E. Gamburd painted the work from the cycle "Restoration of Chisinau" - "View from the Cathedral Park" (gouache, cardboard, $523 \times 656$ $\mathrm{mm}, \mathrm{NMAM}$ ). The dynamics generated by urban transport (tram) and pedestrians in the foreground is balanced by the statics and grandeur of the Cathedral and the Belfry in the background that appears between the trees. The panoramic view is a day of sunny Chisinau, still under reconstruction. Eugenia Gamburd's composition is full of optimism, the author resorting to contrast colours.

Eugenia Gamburd's works have not only artistic but also historical value, the author evoking the period after the Second World War. Unfortunately, none of the author's canvases on this subject were purchased by the Ministry of Culture. Only on the occasion of the 90th anniversary of the painter's birth, some of the artist's paintings were transmitted from the collection of the National Archive of the Republic of Moldova and the daughter's collection in the NMAM funds ${ }^{6}$.

6 "Restoration of Chisinau" (1947-1949) street Pushkin; "Restoration of Chisinau" (19471949) building a department store, The National Archive of the Republic of Moldova, F3170, inv. 2, d. 52, d. 53: f. 1. 


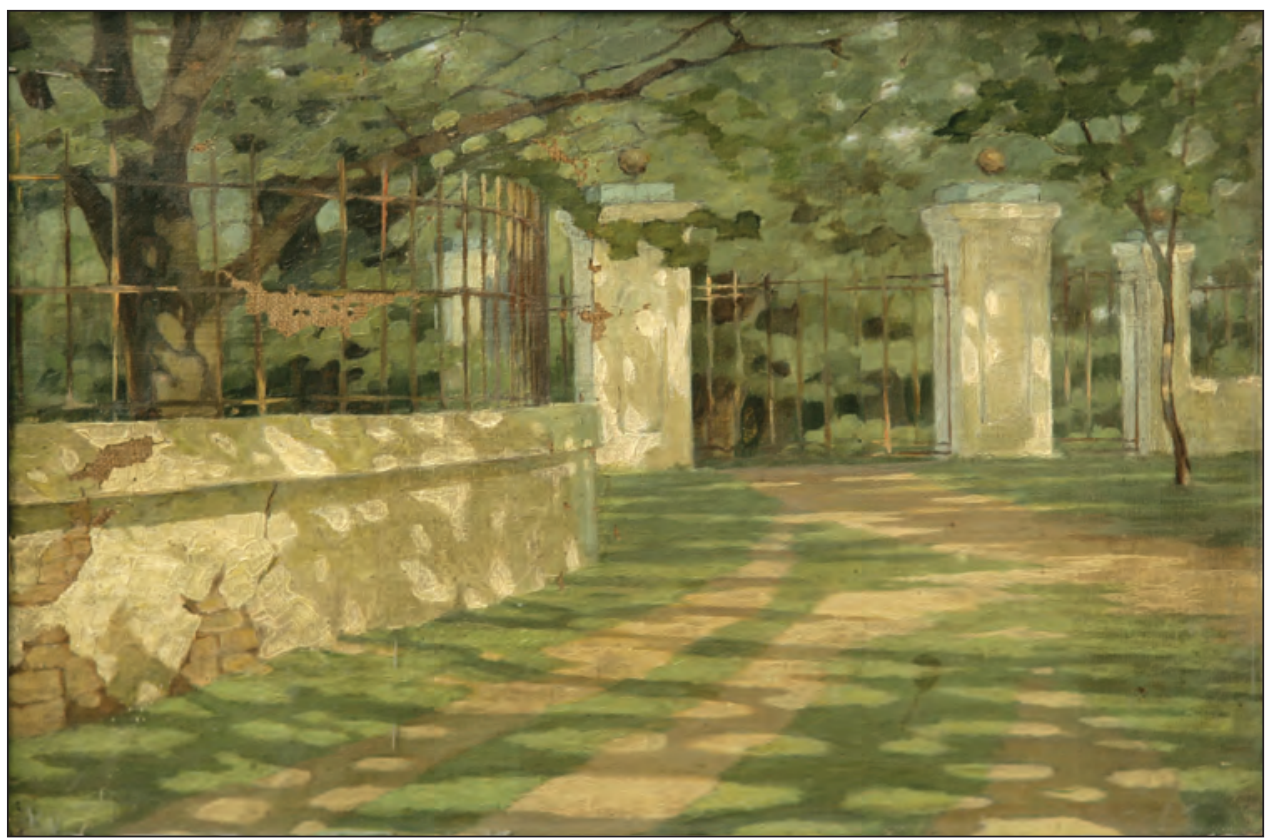

Figure 2. N. Ratok "Entrance to the park in Chisinau", 1908 (oil, canvas, $230 \times 350$ mm, NMAM)

The NMAM funds preserve numerous works with the evocation of the theme of the city from the creation of Mihail Petric, considered "master of the lyrical-panoramic landscape", also called "poet of harmonies"8. Specific to the author's landscapes are the panoramic, realistic, meticulously processed compositions with a rich chromatic spectrum. The image reproduced in the painting "Winter in Chisinau" (1963, oil, canvas, $600 \times 1200 \mathrm{~mm}$, NMAM) approaches the current appearance of the square of the Metropolitan Cathedral of Chisinau. The peace that the canvas emanates is suggested not only by the winter season but also by the image of the mother holding her child by the hand, representing everyday life, the continuity of the nation etc.

Valley of Mills Lakes, Ghidighici, Valley of Roses, were used to be training areas for young athletes, or for children who actively spend their free time, often becoming subjects for painting.

A sequence of the Komsomolist Lake, currently the Valley of Mills, and the surrounding landscape can be found in the work "Study. Chisinau, Komsomolist Lake” (1957, oil, prime textured cardboard, $124 \times 168 \mathrm{~mm}, \mathrm{NMAM})$

7 Ciobanu Constantin. „Un mare peisagist al timpurilor noastre.” Akademos nr. 4/35, (2014): 160.

8 Leonora Sâdnic. Mihail Petric. Biobibliografie (Chișinău: Biblioteca Națională a Republicii Moldova, 2016): 29. 


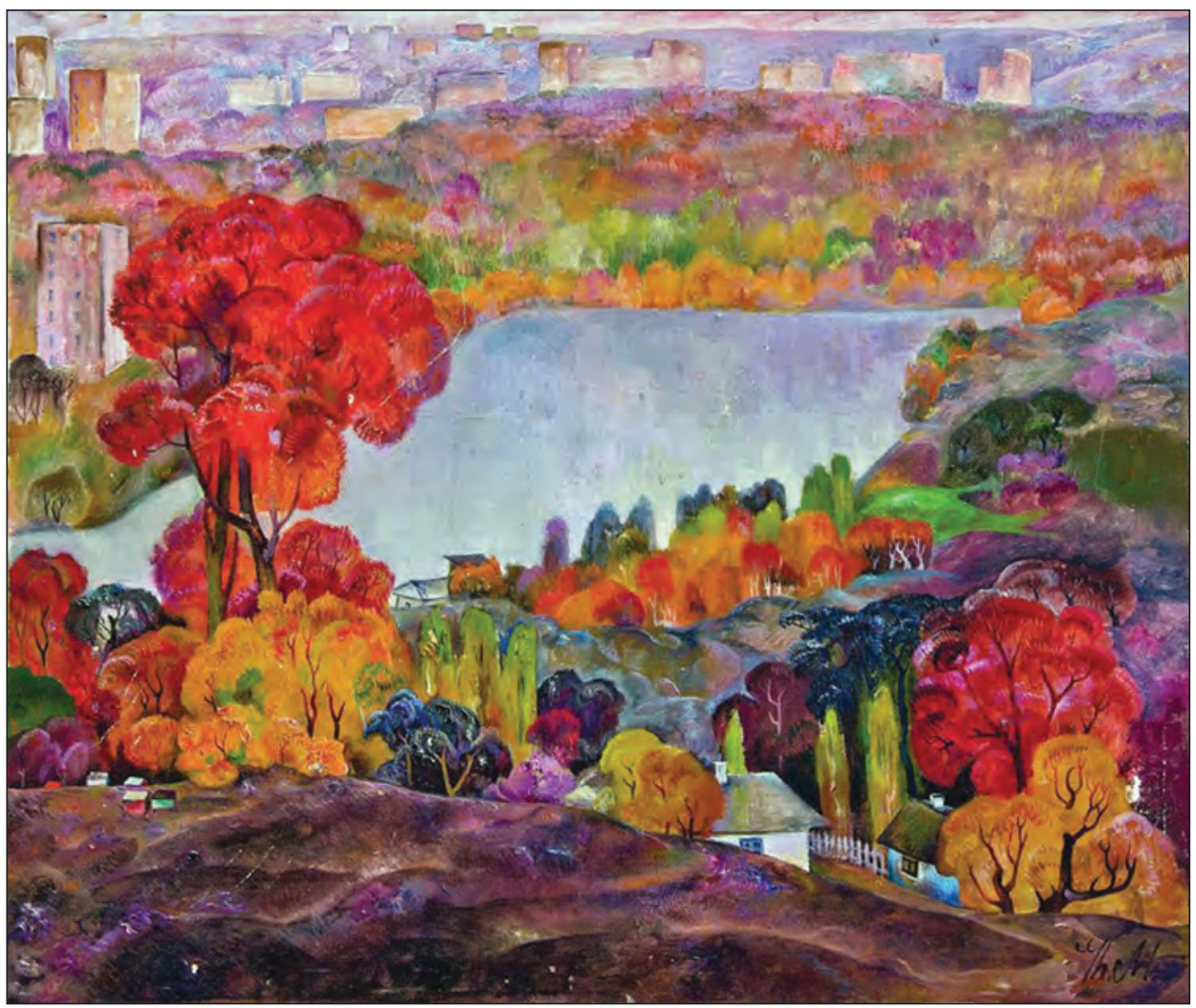

Figure 3. Gheorghe Munteanu "Valley of Mills", 1984 (oil, canvas, 1060×1220 mm).

signed by Rostislav Ocușco. Moreover, Mihail Petric has a panoramic approach in the painting "Komsomolist Lake" (1965, oil, canvas, $600 \times 1505 \mathrm{~mm}$, NMAM), presenting the lake and the surrounding district. The motif of the recreational area, created by the artist $\mathrm{M}$. Petric, continued even later. Thus, in the work, "September" (1975, oil, canvas, $850 \times 700 \mathrm{~mm}$, NMAM) the lake, the surrounding vegetation, but also the city with many blocks that disappear in the distance are painted. The lake is so small that it seems to be dominated by the surrounding vegetation and the industrial area. Thus M. Petric presents the contrast between the creation of nature, with its and of man's peace, with its interventions. In all Mihail Petric's works, the love for the surrounding nature and the care for its preservation are observed.

"In the Valley of Mills" (1973, oil, canvas, $550 \times 575 \mathrm{~mm}$, NMAM), the author Filimon Hămuraru represents a festive event, with the participation of a wide audience. Also, Gheorghe Munteanu dedicated numerous canvases to Valley of Mills Park. The artist in the work "Valley of Mills from Chisinau" (1972, $600 \times 850 \mathrm{~mm}$, oil, canvas) managed to render the picturesque and peaceful 


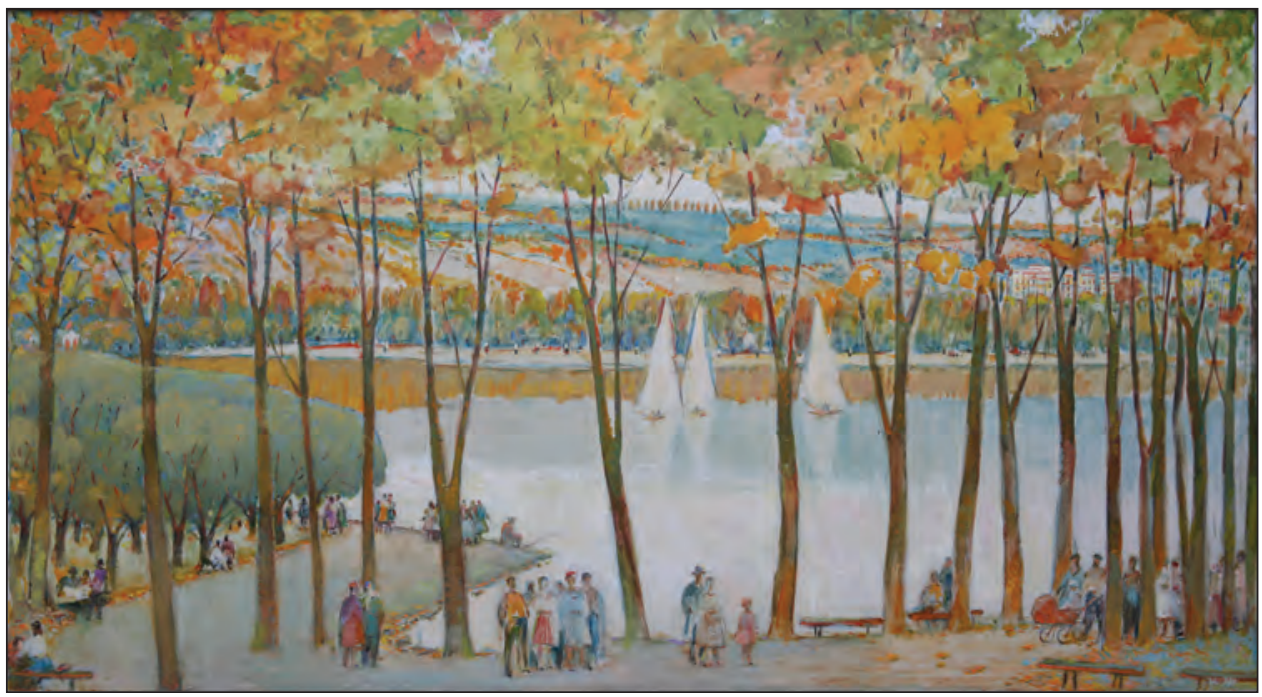

Figure 4. Ion Jumatii "Komsomolist Lake", the 90 s (oil, canvas, $1100 \times 1940$ mm, MNAM).

atmosphere decoratively, with a combination of vivid, contrast colours, a theme he returns to in the next decade in "Valley of Mills" (1984, oil, canvas, $1060 \times$ $1220 \mathrm{~mm}$ ). A graphic approach can be found in the painting "At Valley of Mills" (2012, oil, canvas, $1440 \times 790 \mathrm{~mm}$ ) in which the author presents the park from another perspective, with the staircase, the fountain and the lampposts, the alley and the lake in the silence of the evening, at sunset.

Numerous visitors walking with their families and athletes training on sailing boats are represented in the painting "Komsomolist Lake" by Ion Jumatii (the 90s, oil, canvas, $1100 \times 1940$ mm, NMAM). "Alley at Komsomolist Lake" (the 1990s, oil, cardboard, $965 \times 790$ mm, NMAM) signed by Ion Chitoroaga presents the alley with young poplars, the author solving his problem of falling shadows. The work differs by the dynamics suggested by the alley in perspective and the shadows of the trees planted on its edges.

In an impressionistic manner with a small range of colours, with multiple shades of grey, Florentin Leancă proposes the solution in the work "Lake Valley of Mills" (2012, oil, canvas, $350 \times 450 \mathrm{~mm}$ ). The composition reproduces the solitary motorboat and the reeds that we do not find in the paintings of previous decades by other artists.

Veaceslav Ignatenco 9 dedicated a large part of his creation to Chisinau. The author tries to immortalize the old part of Chisinau, with its narrow

9 A graduate of the Minsk Academy of Fine Arts (1983), Procop Natalia. „Bisericile în plan triconc din Chișinău în viziunea artiștilor plastici.” Dialogica. Revistă de studii culturale și literatură nr. 3, (2020): 122. 
streets, yards and low courtyard houses, transmitting the calm and picturesque rural atmosphere of the city centre. V. Ignatenco also worked on the subject of urban parks. Valley of Mills is an especially attractive area to the artist. The paintings "Chisinau. Spring. Looking at Valley of Mills Lake" (2014, oil, canvas, $500 \times 600 \mathrm{~mm})$, Chisinau. Rotunda. Above the Valley of Mills lake" (2017, oil, canvas, $500 \times 700 \mathrm{~mm}$ ) etc. they differ in the rendering of the state of the day and composition, one of the main features being the dominance of silence. "Chisinau. Spring. Looking at Valley of Mills Lake" is a work that presents the revival of nature, the park being permeated by peace and innocence, and in the distance, you can see the city, the author having mastery in rendering planes. It is a work through which the artist manages to bring back the state of the moment, the atmosphere. "In Chisinau. Rotunda. Above the Valley of Mills lake" V. Ignatenco enlivens the Rotunda and the area nearby, presenting the landscape on a summer day.

Another season evoked by the author is autumn ${ }^{10}$. An author's painting, with a panoramic view, is "Ghidighici Reservoir" (1971, oil, canvas, $800 \times$ $1500 \mathrm{~mm}, \mathrm{NMAM}$ ), which is characterized by the presence of the rich autumn colour, specific to the Moldavian space. Unlike the other works dedicated to Chisinau, we see the composition developed diagonally here, in which the contrasting vegetation in the foreground balances with the waters of the Ghidighici reservoir ${ }^{11}$.

Ghidighici Lake was also painted by Gheorghe Munteanu. The author attracts the attention of spectators by rendering the active spirit of yesterday's society "World Canoe Competition in Ghidighici" (1985, oil, canvas, $1510 \times$ $1450 \mathrm{~mm})$.

"Quiet. Autumn in the Valley of Roses" (1987, oil, canvas, $800 \times 1200$ mm, NMAM) by M. Petric is a work that inspires a state of rest, of a sad day at the beginning of autumn. The silence in the heart of nature is interrupted by the multi-storey blocks in the background, represented schematically.

A special painting by V. Brâncoveanu from his private collection is "In the Valley of Roses" (1980, oil, canvas, $95 \times 120 \mathrm{~mm}$ ). The work is distinguished by a decorative approach to shapes and a contrasting colour range. V. Brâncov-

${ }^{10}$ As M. Petric himself states "I am in love with the Moldavian spring and autumn - these are the seasons of my paintings, seasons that round up rebirth and fulfilment”, Sâdnic. Mihail Petric..., 35.

${ }^{11}$ Water in Romanian mythology is the "eternal source of life", Antonescu Romulus, Dicționar de simboluri și credințe tradiționale românești, 2016. http://cimec.ro/Etnografie/Antonescudictionar/Antonescu-Romulus-Dictionar-Simboluri-Credinte-Traditionale-Romanesti.pdf [accessed 15.08.2020]. 


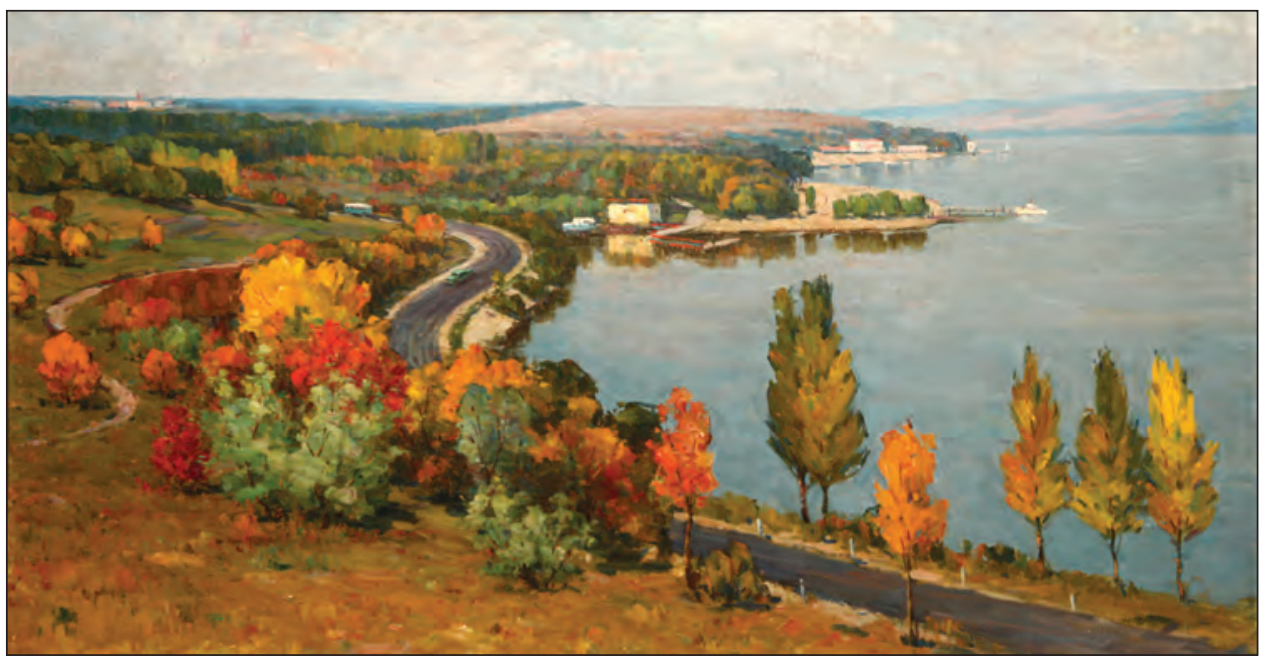

Figure 5. Mihail Petric “Ghidighici Reservoir" 1971 (oil, canvas, $800 \times 1500$ mm, NMAM).

eanu painted the moment of gathering the rose petals, a current activity during the Soviet period. It is a dynamic composition suggested by hills and workers placed in rows. Through composition and decorative, the artist approaches the works from the decorative tint period of the peysagist Eleonora Romanescu, In her paintings, V. Brâncoveanu is distinguished by his chromatic and compositional mastery, by his love for his hometown - Chisinau.

"At the spring. Beach" (1987, oil, canvas, $550 \times 750 \mathrm{~mm}$, NMAM), author Petru Jireghea presents Chisinau residents and guests of the capital resting at the beach. In the distance, you can see an old district, with courtyard houses, and two-storey buildings in the background.

The interaction of the old and the new Chisinau was also a topic addressed by Ludmila T,onceva. The lake often interacts with new constructions, thus immortalizing the capital's architectural changes. "Houses above the lake" (1981, oil, lake, canvas, $1320 \times 870 \mathrm{~mm}$, NMAM) is one of the few compositions in which the author painted the multi-storey buildings. The silence near the lake in the foreground is contrasted with the representations of distant neighbourhoods, with construction sites. The work is made with the predominance of the warm range with multiple shades of pink, ochre.

Another work "Urban landscape. Evening" (1984, oil, $810 \times 810$ mm canvas, NMAM) by the same author represents the city's old part with a relaxation area near a lake with surrounding trees, which contrasts with the huge multi-storey buildings in the back. The painting is made in a cold range of colours with a predominance of shades of blue. 


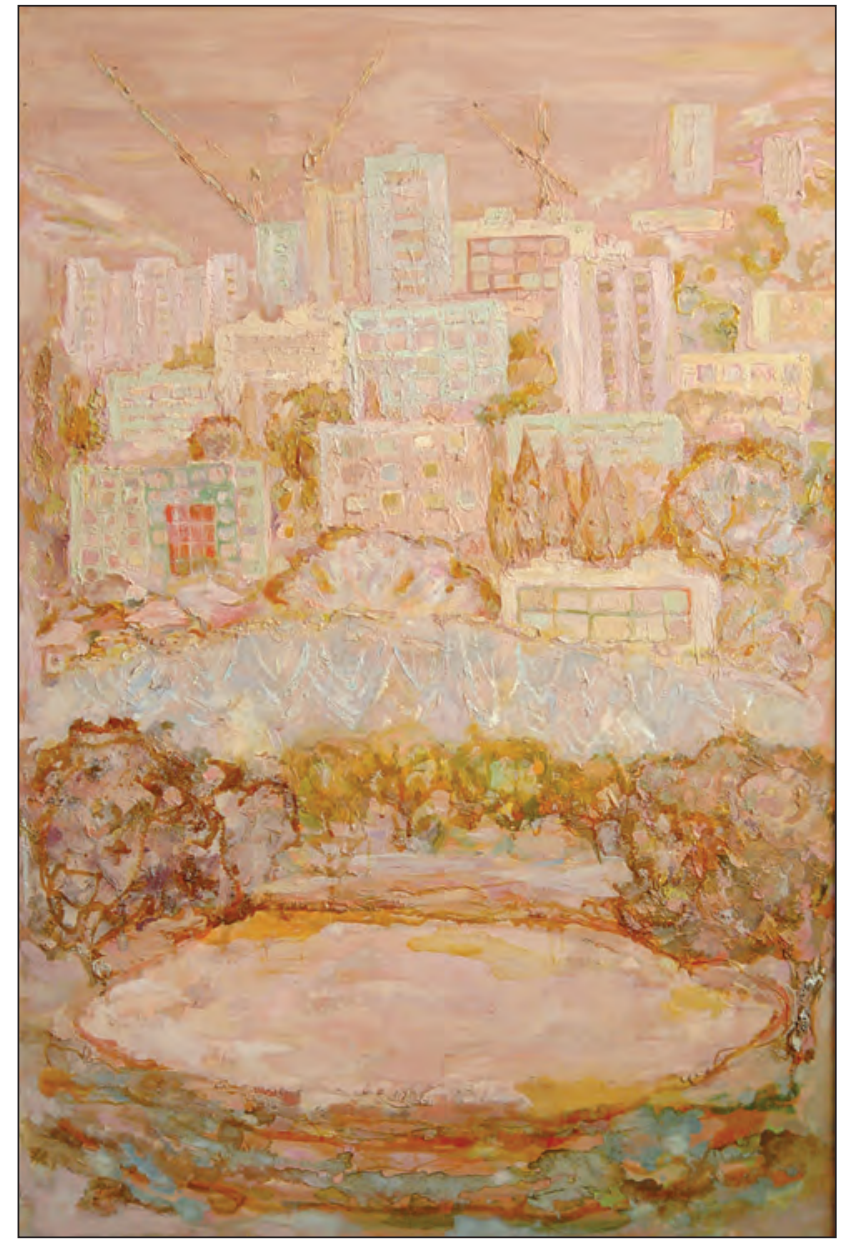

Figure 6. Ludmila Țonceva "Houses above the lake", 1981 (oil, lake, canvas, $1320 \times 870 \mathrm{~mm}$, NMAM).

Ludmila Țonceva realizes a series of works in Plein-air (open-air) at the Botanical Garden: "The ark of roses. Botanical Garden" (1988), "Stars in the Botanical Garden” (1997), “Autumn Flowers. Botanical Garden” (1998). All these paintings have open and dynamic compositions, characterized by intense chromatic and contrasting tones. Being a good connoisseur of art theory and history, L. Tonceva advocated for complex compositions, a wide range of colours, always keeping the individuality that consecrated her.

Botanical Garden was also a source of inspiration for Valentina Brâncoveanu: "In Botanical Garden" (1985, oil, $605 \times 800$ mm canvas), "In Botanical Garden" (1986, oil, canvas, cardboard, $500 \times 700 \mathrm{~mm}$ ), "Autumn in Botanical Garden” (1987, oil, canvas, $450 \times 550$ mm), "In Botanical Garden" (1998, oil, $245 \times 350$ canvas), "In Botanical Garden" (1998, oil, $265 \times 345$ canvas) etc. The artist painted a panoramic landscape with flower fields during the summer period "In Bo- 


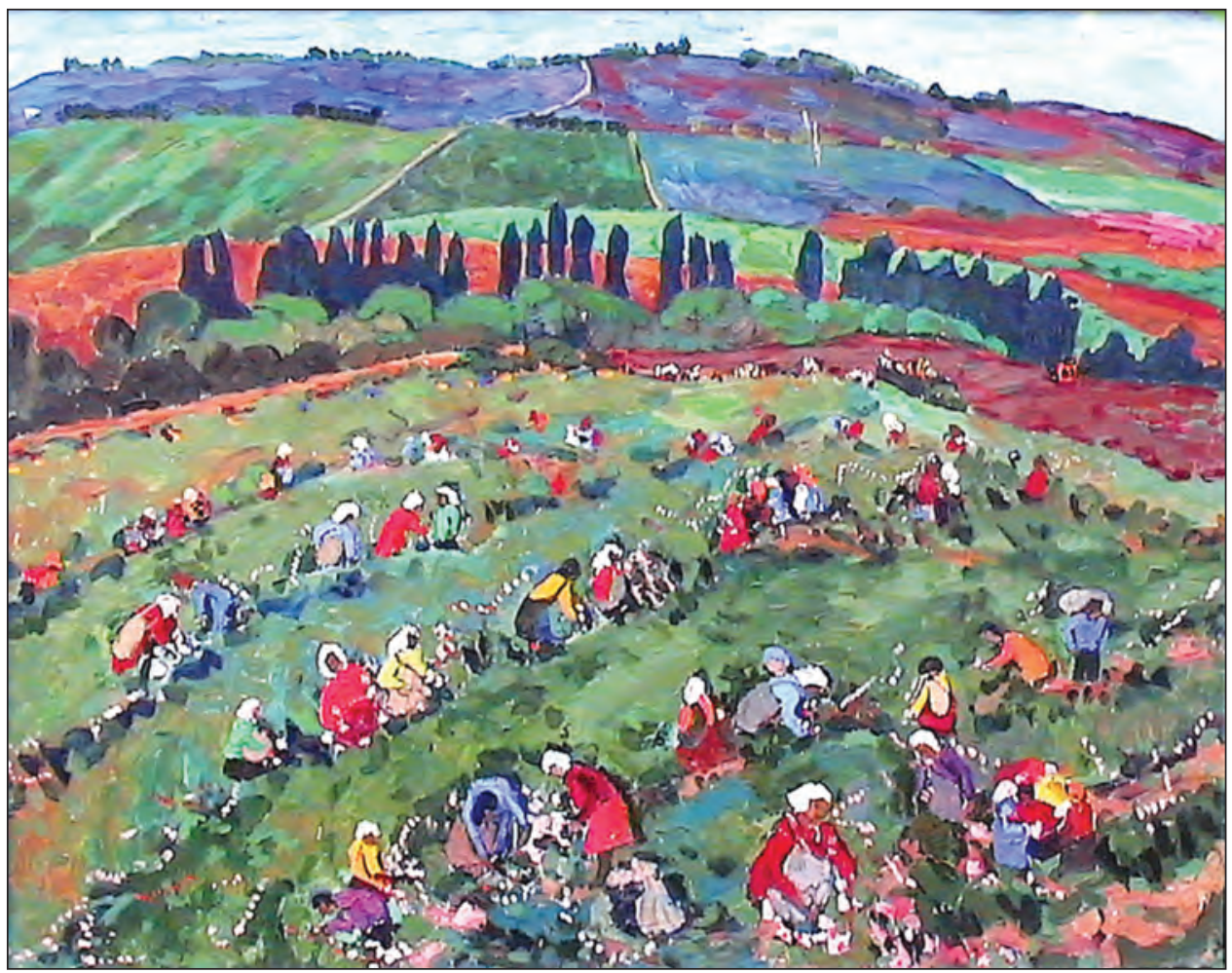

Figure 7. Valentina Brâncoveanu “In the Valley of Roses", 1980 (oil, canvas, 95 × 120 mm).

tanical Garden" (1986), "In Botanical Garden" (1998), or presenting the beauty and colour richness of the autumn "Autumn in Botanical Garden" (1987). In his works, the author also surprised the institution's staff at the time of work.

Another subject that we encounter in the works of plastic artists is the sports fields. The plastic artist Vasile Toma in the work "The sports field of the Pedagogical Institute" (1983, oil, canvas, $880 \times 990 \mathrm{~mm}$, NMAM) evokes the life of young people. The complicated and dynamic composition is suggested by the anthropomorphic figures in action and the tree on the right, which balances with the statics and verticality of the poplars, whose falling shadows also create the sensation of movement. In the compositional realization, the plastic artist draws the attention of the perspective.

The theme of Chisinau sport is also approached in Florentin Leanca's painting. A plastic artist in love with old Chisinau, he painted the work "Dinamo Stadium” (2007-2008, oil, canvas, $500 \times 405 \mathrm{~mm}$ ), a recent acquisition (2013) of NMAM. The artist's study problem is the diversity of the invoice, the chromatic range being reduced to white-grey. The author warns about the change of human values, the stadium being at "rest". 


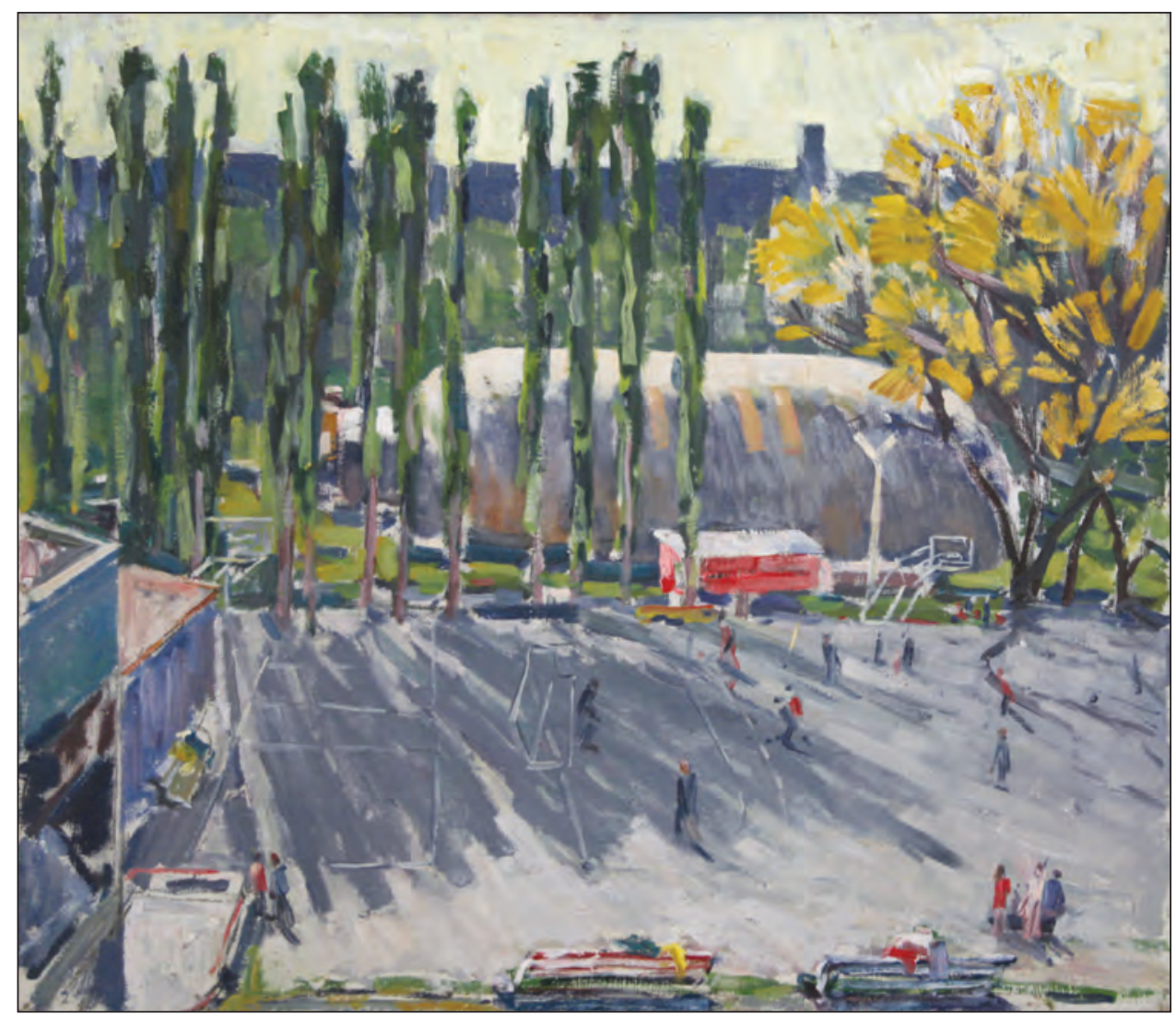

Figure 8. Vasile Toma "The sports field of the Pedagogical Institute", 1983 (oil, canvas, $880 \times 990$ $\mathrm{mm}, \mathrm{NMAM})$.

The recreation area in the vision of Inesa T,îpina - "Recreational Park" (1988, oil, canvas, $900 \times 1200 \mathrm{~mm}$, NMAM), represented by the lively colour range, with the presence of various attractions, so dear to children, emanates positive emotions. The author's works are distinguished by the plastic composition, the chromatic range masterfully directed, by the positive, optimistic atmosphere suggested by the vivid colours.

It should be mentioned that during the Soviet period, the plastic artists were evoking the theme of "labor" more than the subject of "rest". However, the leisure places of the city is a quite simple theme, which bring you back to peace. At the same time, through painting, it can be seen the changes that have taken place over time in the field of reconstruction, reparation of architecture, urban landscape etc. The scientific novelty of the research lies in the fact that this subject has been little studied so far.

Following the evolution of the landscape of Chișinau, we can state that at the end of the 19th century - the beginning of the 20th century the painting 


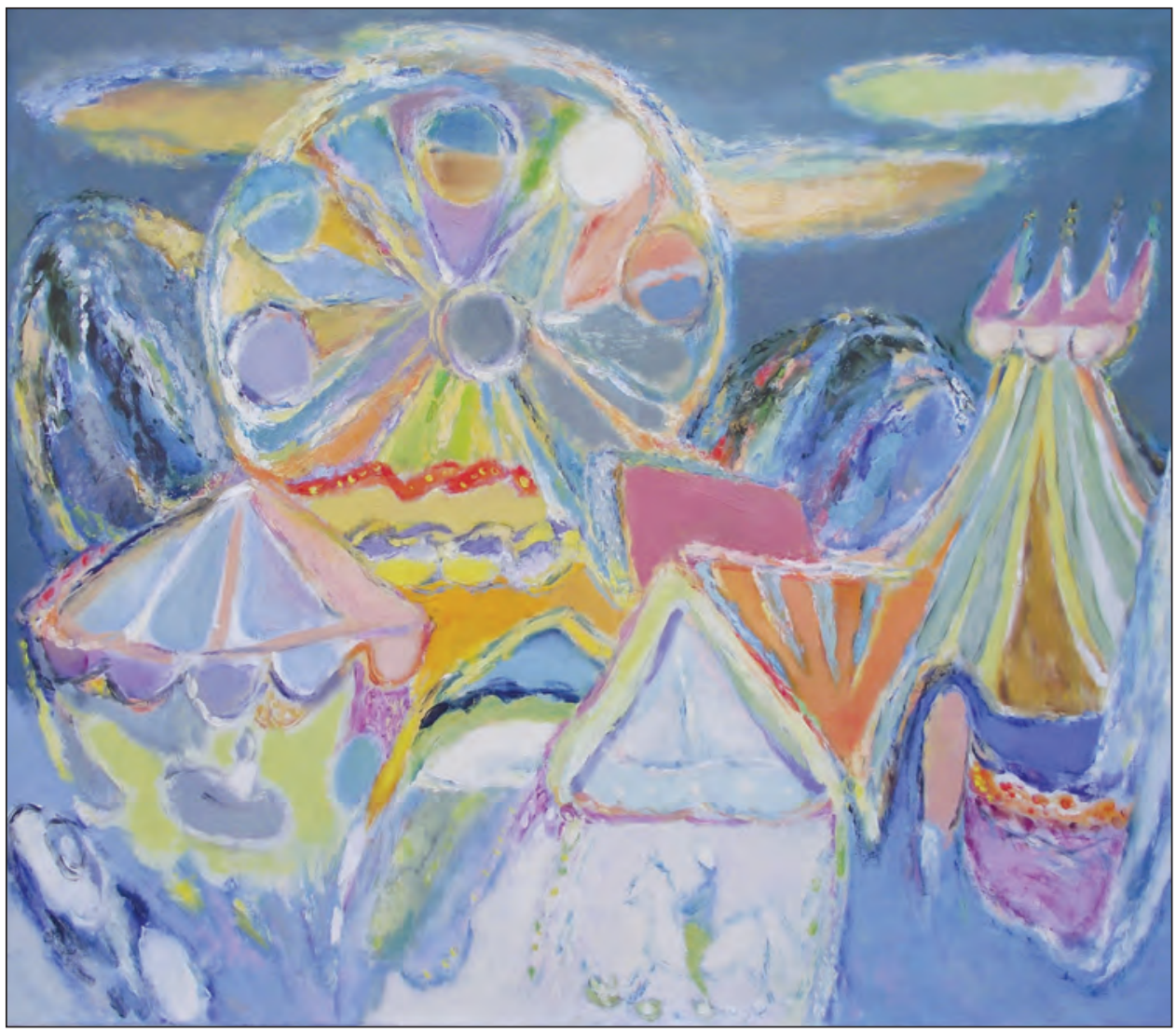

Figure 9. Inesa Țîpina "Recreational Park", 1988 (oil, canvas, 900 × 1200 mm, NMAM).

stands out by realistic, meticulously processed compositions. The paintings from the '70s of the 20th century on the theme of recreational areas of the capital become more decorative, with a brightly colored palette, that are distinguished due to compositional variety. In addition, with the industrialization, the theme of the works changes, thus, it is possible to follow in the compositions the cultural and socio-economic evolution of the city. The genre of landscape is one of the most important in painting, through which we manage to preserve the identity, the national culture, but also to educate the feeling of love for the city, the attitude of patriotism and other behavioral attitudes.

\section{Rezumat}

Unul dintre genurile picturii de șevalet care rămâne mai puțin pretențios politicului este peisajul. Oraşul Chișinău, unul dintre cele mai importante urbe ale republicii, a fost și rămâne motiv de inspirație pentru artiștii plastici: Eugenia Gamburd, Rostislav Ocușco, Mihail Petric, Filimon Hămura- 


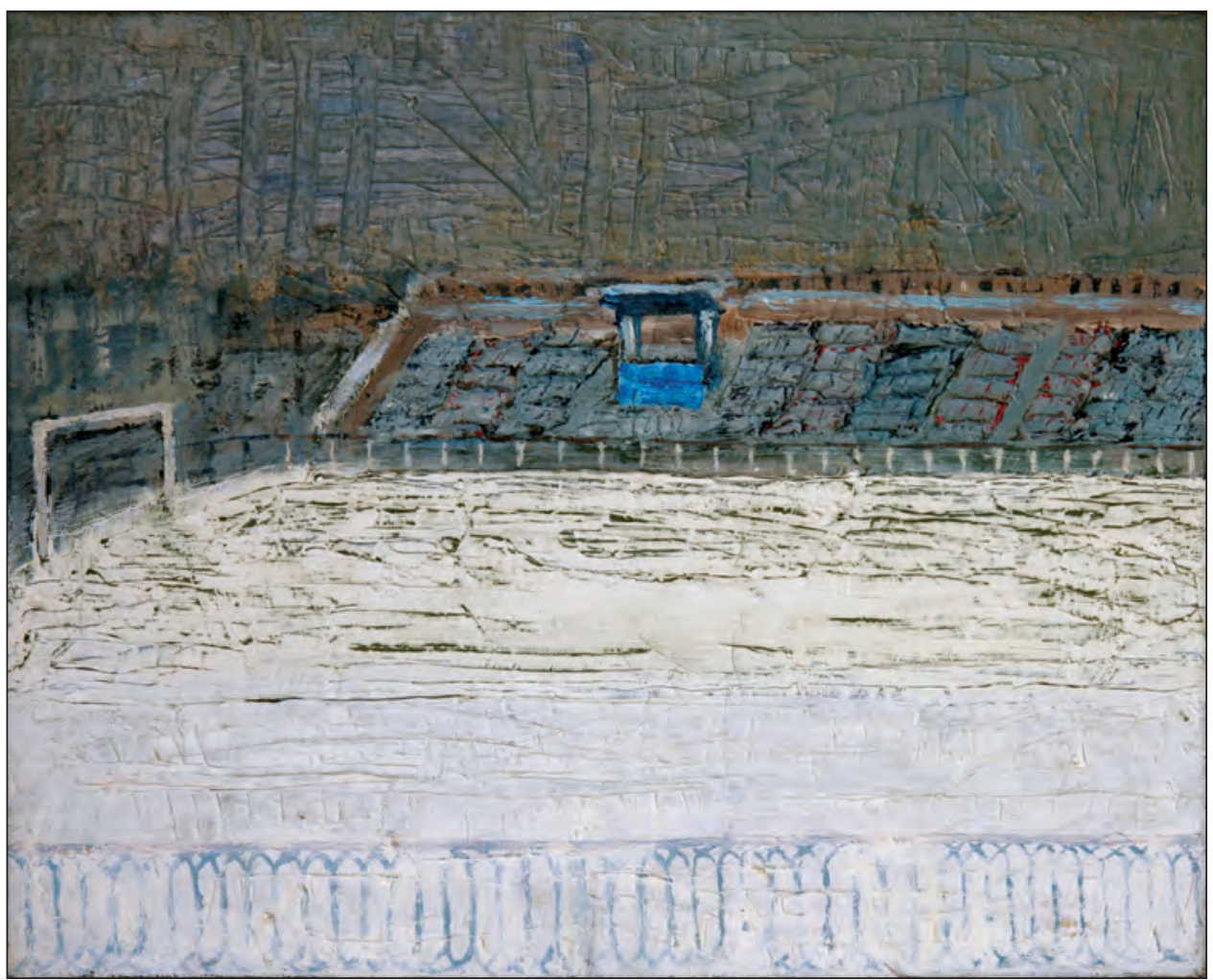

Figure 10. Florentin Leancă "Dinamo Stadium", 2007-2008 (oil, canvas, $500 \times 405$ mm, NMAM).

ru, Ludmila Țonceva, Vasile Toma, Inesa Țîpina, Petru Jireghea, Ion Jumatii, Ion Chitoroagă, Florentin Leancă ș.a. Unul dintre subiectele abordate de plasticieni, ce reflectă momentele de relaxare, odihnă, sport sunt centrele de agrement (parcurile, lacurile, stadioanele etc.). În articolul de față sunt analizate picturile din colecția Muzeului Național de Artă al Moldovei, dar și din colecțiile private ale plasticienilor cu referire la zonele de odihnă a Chișinăului. Aceste picturi realizate la tema supusă cercetării pot fi atribuite nu numai genului peisajer, dar în unele cazuri picturii de gen. Subiectul devine actual pentru pictori odată cu amenajarea parcurilor capitalei: Scuarul Ansamblului Catedralei Mitropolitane din Chișinău, Grădina publică din Chișinău, Grădina Botanică, parcul Valea Trandafirilor, parcul Valea Morilor, Lacul de acumulare Ghidighici, Stadionul Dinamo ș.a.

Cuvinte-cheie: Chișinău, centre de agrement, artă vizuală, pictură.

Natalia Procop, Institute for Research and Innovation of the State University of Moldova, e-mail: natali_procop@yahoo.com 